\title{
Socio-Statistical Characteristics of Informal Employment
}

\author{
Evgeny A. Belov ${ }^{1}$ \\ ${ }^{1}$ Kazan Law Institute of the Russian Interior Ministry, Kazan, Russia \\ Correspondence: Evgeny A. Belov, Kazan Law Institute of the Russian Interior Ministry, Orenburgsky tract 128, \\ Kazan, 420059, Russia.
}

$\begin{aligned} & \text { Received: October 24, } 2014 \\ & \text { Accepted: December 3, } 2014 \quad \text { Online Published: December 18, } 2014 \\ & \text { doi:10.5539/res.v7n1p182 }\end{aligned}$ URL: http://dx.doi.org/10.5539/res.v7n1p182

\begin{abstract}
Relevance of the investigated problem is due to the non-receipt of the substantial money supply in the government budget from taxes and insurance premiums, as well as due to the destruction of the legal and moral standards in the work world. The purpose of the article is to demonstrate a constructed model of socio-statistical evaluation of the employment relationship deformity. The leading methods for researching this problem within the scope of the work done were a survey and secondary analysis of official statistical data. The result of this work is in identifying the most important criteria for evaluating informal employment, which can be used in the framework of further sociological research on the subject.
\end{abstract}

Keywords: informal sector, unofficial labour market, informal employment, underground employment, informal economy, labour force

\section{Introduction}

The informal segment of the labour market reorients itself to significant public resources and distorts labour relations. Moreover, informality as a deviation from the officially established order can exist without exception in all forms of employment in varying degrees and in varying forms (Klyamkin, 2000). In our case, by informal employment we mean any activity in producing legal (allowed for sale) goods or services by parties without proper rights (labour agreement, employment contract, license, permit, etc.) for this type of activity, and the activities of households that are engaged in the manufacture of goods and services for the market and do not have the legal status of a legal entity (Belov, 2014; Gimpelson, 2014). The reasons for violations in the sphere of labour recruitment are caused both by socio-economic factors and lack of employers' and employees' legal culture. In addition, poorly developed mechanisms of control and supervision over the observance of labour legislation create the preconditions for committing certain offenses. To study this phenomenon it is necessary to determine the methods of sociological research and specify the estimation parameters (Yadov, 2003). Representativeness of any research depends on the correctness of the sampling and accuracy in comparing different evaluation criteria of the considered object. For the sole purpose of disclosure of the total population characteristics in the Russian Federation informal employment, an algorithm for estimating the deformation of the employment relationship was designed and tested, which is proposed within the scope of this article.

\section{Materials and Methods}

In order to identify internal and external factors causing the informal employment, we have analyzed two major groups of sources. The first one includes the results of studies conducted by the Federal State Statistics Service (FSSS) and the territorial bodies of the Federal State Statistics Service in Tatarstan Republic (TB SS in RT). The second group includes data of sociological research of the Analytical Research and Development Center, with or under the supervision of the author. The primary research was conducted in October-November 2005. The sample population amounted to 1484 people. The method of collecting the primary data was interviewing (Belov, 2006). The next was empirical case study carried out in Kazan city in the third quarter of 2013. The sample volume consisted of 350 people. The research method was individual, unstructured interviews. The sampling error was $5 \%$. The third step included the results of three focus-groups consisting of eight people in each, conducted with the persons who, according to the results of the interviewing, were categorized as the informally employed, and the adjusted parameters of the informal labour market segment, obtained under the repeated (trend) research conducted by the author. 


\section{Results}

According to Rosstat, by the end of 2013 the total number of the employed population was 71.4 million people (Rosstat, 2014). Given the fact that $19.7 \%$ of the indicator falls on those employed in the informal sector, their total amount is within the 14.1 million people. According to most experts, this figure is somewhat understated, but even it indicates a serious problem in the work world. It should be noted that official statistics evaluates only the economic activities carried out on the basis of households that are engaged in the production of goods and services for the market and do not have the legal status of a legal entity. But informality appears not only at this level. Moreover, parties carrying out activities for the production of legal (allowed for sale) goods or services, but without having the proper rights for it (employment agreement, service contract, license, etc.) and not considered as subjects of the informal sector, have a more distorting effect on the employment relationship, rather than representatives of the previously selected group. To date, there are no methods to assess the number of informally employed people, but there are all the opportunities for the calculation of this category of workers. This requires correct and coordinated activity for collecting and processing data from different organizations (tax office, pension fund, the Ministry of Labour and Social Development, the Federal State Statistics Service, etc.).

Conducting random sociological research is impossible without correct formation of the population sampling. In turn, in conducting research of informal employment and the informal sector of the economy it is extremely difficult to include foreign nationals and stateless persons in the sampling, who are carrying out work on the territory of Russia. Although, according to various experts, their number varies from 5 to 20 million people. Notably, informal employment in this category is also evaluated on the basis of experts' opinions, without demonstrating calculated indices.

It seems to us that these data reports of the Federal Migration Service in RF (FMS of Russia, 2014) and a number of other open sources will allow with arguments and with the smallest error to determine the number of migrant workers engaged in informal labour activities in our country. As absolutely accurate information we can assume that in 2013 approximately 17.3 million foreign citizens entered Russia. When crossing the Russian border every foreigner is obliged to fill in a migration card. One part of the migration card is dealt at the gateway to Russia, the other - at the checkout. In case of loss of the second part of the card a foreigner leaving Russia must fill out a new card-it can be correlated with the old one by the number of the passport. All of this is entered into the database, which means that this database has information about all the foreigners who legally got on the territory of Russia. If to subtract persons of unemployable age from this figure, i.e. younger than 16 and older than 60 years old, students, tourists (Rosturizm, 2013), visitors from countries with developed economies, people who came to Russia for family and private matters (Federal Migration Service, 2014), and so on, we obtain that about 12.7-13.2 million foreigners arrived to work. Of these, about 2 million workers had originally envisaged for themselves engaging in formal employment relationships, i.e. received a patent, work permit or had been issued as qualified labour force. A patent does not give the right to work in a legal entity, and the work permit does not give the right to work for a private individual. Therefore, one and the same person during a year could receive both a work permit and a patent. So far there is no statistics of granted patents for a period of one month or three, of re-issued patents to the same person, obtained work permits for a period of three months or a year. Accordingly, the information could only be obtained by interviewing foreign workers, taking into account a certain percentage of error. This work was performed during the research, which explains the resulting figure. It turns out that in 2013, the Russian Federation border was crossed by more than 10 million foreign nationals oriented to informal employment. In addition, we have not considered stateless persons (Chedzhemova, 2013) and foreign nationals who were already in Russia illegally, i. e. they had not crossed the border. Accordingly, during a year at least 14 million foreigners and stateless persons are working on the territory of Russia, with whom the employment relations are not properly formalized.

In modern social science a clear methodology has not yet been developed for identifying patterns of functioning and development of informal employment relations. In addition to the above, in some studies there are certain algorithms (Barsukova, 2004; Kapelyushnikov, 2014; Syniavskaya, 2005), which were taken as a basis for conducting our own research.

According to the research, the main part of the informal labour market is composed of people aged 30 to 49 years old. Workers in this age group are the most competitive. They are of a good professional experience and are in the highest demand in the labour market. It should be noted that workers in this age group are the most effective in terms of productivity for most industries and the service sector, because their skill is correlated with physical and mental health of the body. In fact, the falling out of this particular group from the scope of legal work most painfully affects the socio-economic ties and relations. 
Noteworthy is the fact that about $15 \%$ of the active part of the population has unregistered employment as additional. And sufficiently clear link is traced between age and the presence of employment as not the primary job. So, if in the age group 45-59 years old, the proportion of persons who have regular extra work was $7.5 \%$, then in the group of $18-24$ years old $-19.4 \%$. Additional employment is predominantly informal. At that, for the majority it is episodic or random. Thus, according to the survey, more than $60 \%$ of the secondary employment is engaged in additional work from time to time, without filling out an employment contract. This allows the employer to evade payment of some taxes. The employees, in turn, get the opportunity to better meet their needs, because salaries at the primary jobs do not allow doing it. Unformalized labour relations attract by their optionality not only employers, but also employees, because they free them from moral, disciplinary and other liabilities for ineffective and poor quality labour activities.

The average utilization of the secondary employment in the informal labour market is 2-4 hours per day. Moreover, one third of them do not work more than two days a week. This duration of employment is most common in the age group of 25-34 years old. At the same time one third of the 18-24 years old age group representatives are in additional employment in the informal labour market for five days or more.

According to the Federal State Statistics Service, more than a third of the informally employed have secondary (full) education, which is quite natural. Perhaps this suggests that quite a large number of people with secondary education cannot find jobs that meet their needs in the sphere of formal labour relations. And they are willing to sacrifice various kinds of guarantees for the sake of obtaining livelihoods funds.

Attention should be drawn to the fact that about $60 \%$ of informally employed individuals with secondary education do not plan reorientation to formal employment relationship in the future, thereby fully associating themselves with a certain segment of the labour market. The education area of the informally employed is quite diverse and not fully understood. For example, out of Rosstat experts' view there remains a question concerning the education level of individuals who are engaged in informal employment relationships outside the primary place of employment. In such a case in the framework of our research, we have determined the fact that the majority of persons in this category have higher education. In fact, half of them had an extra constant (not the primary place of work) informal employment. Given the fact that a fifth of all the informally employed are people with higher education, it turns out that in the informal labour relations no less than $60 \%$ of college graduates are involved. About half of them have received state-subsidized education, i.e. training for the informal segment of the labour market was paid for from the state budget.

Indicative is the fact that individuals with advanced degrees (postgraduate professional education) are practically not represented in the informal labour relations as permanent employees. However, these highly qualified professionals make up a tenth part (11.7\%) of the informally employed having the regular extra work. This figure cannot be ignored, because there is a serious interest, of those having a postgraduate (candidate) and doctoral academic degrees, in informal employment.

Given that the average for this type of one person's employment accounts for about 14 hours per week, we can judge sufficiently large expenditure of high professional capacity outside of the formal employers' interests.

Accordingly, it is necessary to identify the causes of this phenomenon and to develop mechanisms to prevent withdrawal of a large number of workers with higher and postgraduate professional education to the field of informal employment.

The informally employed used to study mostly the humanities. This is due to the fact that the impossibility to find work in the specialty field most often leads to rejecting formal rules of employment in favor of earnings at any cost. Individuals who leave the profession, in a short period of time lose their proper knowledge, skills, and, accordingly, the appeal as professionals. At that the work in the trade, learned in an educational institution, is the key to formal employment. However, it is noted that to date in Russia $60 \%$ of residents do not work in the area of expertise as specified in their (College/Degree) Certificates. This again points to the need of serious steps in reforming the education system and linking it with the system of employment and employability. Perhaps the reorientation of budgetary funds for training engineering and technical personnel, which is planned from the next year, is quite justified.

The findings of the research contradict a conventional opinion regarding the fact that the informal labour market involves the most uncompetitive (the elderly, the youth, the poorly educated) groups of individuals. Accordingly, the development of government programs to stimulate formal employment of educated and experienced labour force is of vital importance, while avoiding their extensive withdrawals into the informal sector.

Informal employment is concentrated in such areas as trade and repair of household goods, construction and 
repair of housing. Our research results are somewhat different from those obtained by Rosstat. This is due to slightly different evaluation and quality criteria of the sample. Taking into account the analysis of a number of factors, a large proportion of the informally employed should be noted in agriculture and forestry. Their number is actually comparable to the trade sphere.

Considerable quantity of people, concentrated in trade, agriculture, construction, is due to the fact that these industries are dominant in number of those employed in the economy. Along with that, these sectors account for a large amount of work which falls on the middle and low-skilled, who are most involved in the informal labour market. The sectoral structure of the informal employment is most likely due to the processes of denationalization of the economy. It was exactly in trade, construction, service sector, when non-state patterns of ownership initially began developing and became most widespread, favoring the expansion of informal labour relations. In the private sector, the informally employed work mainly in enterprises employing fewer than 20 people. That said, the increase in the number of employees at a company in most cases leads to a reduction in the professional core of the organization, in the proportion of those who are working on the terms of unregistered employment.

Characteristic feature is the fact that a key area of informal employment is trade. Therewith special attention should be paid to its market segment. Urban merchandise and food consumer markets represent the largest component of the contemporary informal economy anywhere in the world, being a center of not only legally unexecuted employment relationship, but also a place of irregular migrants and shady business concentration. In Russia, according to expert estimates, these markets absorb up to $15 \%$ of the economically active population (i.e., not less than 10 million people) as employees and entrepreneurs, besides more than $90 \%$ of the latter, being essentially self-employed, do not have and do not seek to acquire the legal status and therefore do not carry the obligations associated with the status (payment of taxes, transaction processing, reporting, certification of goods, etc.).

Slightly different is distribution of workers according to the spheres of activity among the secondary informally employed. Based on the survey results, we note that most of the individuals having an additional unregistered employment, work in construction. Trading takes the second place. At the same time, when analyzing the informal employment, we observed the opposite. Perhaps this suggests that in trade the priority is given to permanent workers, albeit informally employed, while in construction it is beneficial to involve ad hoc workers.

Among the most significant indicators of the informal employment role for the employee is the amount of earned income. According to some experts, the attractiveness of informal employment is primarily due to higher salaries. However, analysis of the distribution of income from informal employment shows that only top managers and entrepreneurs have income above the subsistence level. Moreover, if workers form an intermediate group, then the other members of the informal labour market have incomes below the subsistence minimum.

The main activity of a student is studies, work is considered as secondary. Besides, it is necessary to create additional working conditions for a student with formal employment. An employer can agree to this only upon the condition of government subsidies and benefits, which today is poorly practiced. The retired, because of health status and other factors, are also unattractive to the employer. In turn, they have a certain pension, and any additional earnings only strengthen their position. So it is natural, that the representatives of these two groups are ready for almost any pay of their work for a slight improvement in their life quality. If we exclude students and pensioners, it turns out that about $40 \%$ of those employed in the informal labour market have incomes below the subsistence minimum. These figures are somewhat inconsistent with common reference numerals.

Quite a number of the informally employed are focused on maintaining a minimum standard of living. Their income is only enough to meet basic needs. Besides, even those who said that informal employment allows maintaining the average level of consumption, mainly talked about the possibility of buying food and things, i.e. there was absolutely no question of proper living. As the main bonuses of informal employment the respondents noted not a higher income but flexible hours or low requirements to the quality of the performed work. For the majority of the informally employed the income is not more than 17 thousand rubles. While the average wage in Russia in 2013 amounted to 29.9 thousand rubles (Rosstat, 2014). Only 7\% of the informally employed respondents indicated that their income exceeds the average wage. Perhaps workers in the informal segment of the labour market were not willing to fully disclose their income. However, even if we consider that the real wages of the "informals" majority are slightly above the stated ones, it does not significantly change the overall picture. Beyond that, about $30 \%$ of the respondents have an income around 10 th. rubles, which determines their position below the poverty line. This fact may indicate the employers' predatory use of workers, who are not in formalized employment relationship. These workers in view of weak competitiveness are ready to be paid a 
minimum of their labour, what certainly affects the quality of the resulting product.

The primary jobs began to lose their priorities in terms of the basic labour costs application and obtaining basic income. Most of those who were busy in their primary jobs in the public sector and had extra work would devote to the latter more than 28 hours a week. According to the surveys of the population, conducted by the Federal State Statistics Service in 2013, 26594 man-hours were worked out outside the principal place of employment. On average, one who had an extra job would have 14 work hours per week. These figures indicate a fairly high need for workers in the secondary sector employment. And the modern labour market is not saturated with the required number of formal jobs providing secondary employment. This, as it was noted earlier, determines the fact of a significant number of workers' informal secondary employment.

In the unregistered employment there is high labour intensity. The average workweek of the informally employed is about 50 hours (Varshavskaya, 2011). At the same time $2 / 3$ of them works for about 40 hours during the week, which correspond to the workload of an employee having a formalized job. Accordingly, 1/3 of the informally employed works more than 50 hours a week, and that is a direct violation of the labour legislation. At the same time the workers themselves prefer not to make demands on the reduction of the excessive workload, compensating for it by optionality to fulfill certain norms. Moreover, this situation is due to the fact that many workers are willing to sacrifice their free time, which is given to them by the employer for the opportunity to earn additional income. In addition, for the employer himself it is more profitable to pay extra for their overtime than to hire another employee.

The results of our research slightly differ from the data presented by E. S. Kubishin (Kubishin, 2003). However, the basic positions have not changed. Thus, the main part of the informally employed is local residents, which account for $48 \%$ of this population. The next largest group consists of the neighboring countries citizens, they, according to our estimates, constitute $27 \%$ of all the informally employed. The third position is occupied by residents of other regions of Russia with an index of 19\%. The fourth group consists of citizens from far abroad countries, which constitute not more than $4 \%$ in the structure of the informal segment in the labour market. The number of the informally employed individuals without citizenship is about $2 \%$. Thus, more than a third of the informally employed are foreign nationals. If we start from our earlier value of 14 million foreigners and stateless persons involved in the informal labour relations, then it turns out that the total number of the informally employed is 56 million people, and the Russians among them are 42 million.

It should be noted that for the majority of the informally employed this activity is stimulated. Employees are ready at the expense of personal time, health, and the like, to perform labour activities. Eventually at stake there is physical and mental health of a significant part of the population involved in the informal labour relations.

\section{Discussions}

In its scope and importance the informal employment is a relatively new form in the national system of social and economic relations. This causes an insufficient level of knowledge of this phenomenon for public policymaking. Although it is impossible not to note the fact of the increasing interest in the theoretical and practical understanding of this problem. Among the sociological works devoted to general theoretical problems we can distinguish the proceedings of S. Y. Barsukova (Barsukova, 2004), E. Y. Varshavskaya (Varshavskaya, 2014), V. E. Gimpelson (Gimpelson, 2014), T. I. Zaslavskaya (Zaslavskaya, 2004), R. I. Kapelyushnikov (Kapelyushnikov, 2012), I. M. Klyamkin (Klyamkin, 2000), Y. V. Latov (Latov, 2006), V. V. Radaev (Radaev, 2003), O. V. Sinyavskaya (Synyavskaya, 2005), and others. The analysis of the works of these authors gives an indication of the fact that presently there is no clear categorical apparatus, the regularities of the phenomenon under investigation are not completely disclosed, and a unique typology of informal practices is not developed, and so on. Besides, the research base of these works is primarily brought about by the results of their own research, and not by a comparison of official statistics with other information.

\section{Conclusion}

Overall, the results of the work done allow to judge about getting statistical data that can reveal the role and importance of informal employment in the society's life activities. Certainly, we do not claim having defined all the parameters of the informal labour market segment. It is almost impossible to do so within a single study. Accordingly, in the long term our proposed algorithm for the statistical evaluation of informal relationships at the work world will be refined and improved, allowing a more qualitative assessment of the social phenomenon under study.

\section{Recommendations}

The article submissions may be useful for humanities teachers, students within the socio-economic profile, 
and professionals, whose career interests include issues of informal employment.

\section{References}

Barsukova, S. J. (2004). Informal Economy: Economic and Sociological Analysis (p. 448). Moscow.

Belov, E. A. (2006). The population in the area of underground employment: Socio-legal aspect of the study (p. 108). Kazan.

Belov, E. A. (2014). Organizational and legal ways to prevent deformation of the employment relationship (p. 157). Kazan.

Chedzhemova, M. (2013). Nobody knows how many individuals are stateless in Russia. Retrieved from http://piter.tv/event/Madina_Chedzhemova_Nikto_/

Gimpelson, V. E., \& Kapelyushnikov, R. I. (2014). In the shadow of regulation: The informality in the Russian labour market (p. 536). Moscow.

Kapelyushnikov, R. I. (2012). Informal employment in Russia: What do alternative definitions say? (p. 84). Moscow.

Klyamkin, I. M., \& Timofeyev, L. M. (2000). Shady Russia (p. 595). Moscow.

Kubishin, E. S. (2003). Informal employment in Russia. ECO, 2, 160-176.

Latov, Y. V. (2006). The underground economy (p. 341). Moscow.

Radaev, V. V. (2003). The informal economy and non-contractual relations in Russian business (p. 130). Moscow.

Rosturizm. (2013). In 2013, the number of foreign tourists coming to Russia rose to 2 million people. Retrieved from http://www.sdelanounas.ru/blogs/45642/

Sinyavskaya, O. V. (2005). Informal employment in modern Russia: Measurement, proportions and dynamics (p. 55). Moscow.

The Federal Migration Service of Russia. (2014). The official website. Retrieved from http://www.fms.gov.ru/about/statistics/data/details/81106/

The Federal State Statistics Service of Russia. (2014). The official website. Retrieved from http://www.gks.ru/wps/wcm/connect/rosstat_main/rosstat/ru/statistics/wages/labour_force/

Varshavskaya, E. Y. (2014). Informal wage workers (pp. 683-692). Moscow.

Yadov, V. A. (2003). The strategy of sociological research (p. 596). Moscow.

Zaslavskaya, T. I. (2004). Modern Russian society. Social transformation mechanism (p. 400). Moscow.

Zubchenko, E. (2014). 60\% of the population today does not work in the area of expertise as specified in their (College/Degree) Certificate. Retrieved from http://newsland.com/news/detail/id/1016192/

\section{Copyrights}

Copyright for this article is retained by the author(s), with first publication rights granted to the journal. This is an open-access article distributed under the terms and conditions of the Creative Commons Attribution license (http://creativecommons.org/licenses/by/3.0/). 